\title{
Personal values and trust of Europeans in national and EU institutions
}

UDK: 316.752:061(045)

\section{Marjetica Primožič}

Slovenian Research Agency

marjetka.primozic@guest.arnes.si

\section{Cene Bavec}

University of Primorska, Faculty of Management Koper

cene.bavec@guest.arnes.si

\section{ABSTRACT}

The paper elaborates influence of the personal values of Europeans on their trust in national and EU institutions. We confirmed the hypothesis that personal values have no effect on this trust with an exception of citizens' attitudes towards democracy and tolerance. In the countries where democracy is a strong personal value citizens also demonstrate high trust in national institutions, on the other side in the countries where solidarity is high valued they demonstrate high trust in EU institutions. Furthermore, we confirmed that there are statistically significant differences in trust in institutions between citizens of the old and the new EU27 member states, as well as differences in countries with different types of legal systems. In majority of the new EU members citizens have higher trust in EU institutions, but lower trust in national institutions than the EU average. On the other side, the old EU members demonstrate higher trust in national institutions and much divided trust in EU institutions. We also indicated that characteristics of the national legal system influence citizens' trust in national institutions, but they have no influence on trust in EU institutions. Countries with the Scandinavian national legal system demonstrate very high trust in national institutions, meanwhile trust in national institutions in post-socialistic countries is nearly three times lower.

Key words: personal values, trust, national institutions, EU institutions, legal systems, EU member states

JEL: COO 


\section{Marjetica Primožič, Cene Bavec \\ Personal values and trust of Europeans in national and EU institutions}

\section{Introduction}

Many researches reveal significant differences in the Europeans' perception of national and EU institutions (Kaase, 1999, McLaren, 2002, Eurobarometer, 2008). The European Commission regularly follows and publishes related researches and public opinion polls because they are important indicators of cohesiveness and acceptability of the EU among general European public. These researches confirm differences between EU regions and countries that are relatively stable over time. There are many possible explanations of this phenomenon, depending on researchers' view and selection of observed indicators (Hudson, 2006). The most common justifications are based on historical grounds and diverse political and economic development in the particular country or region. It is a quite convincing explanation in the case of the new EU member states, because the majority of studies confirm differences between the old and new member states which are reflected in numerous political, economic and social indicators (Hofstede, 1998, Halman, 2001, Bavec, 2007). Many differences could be attributed to the lower level of economic development and also some political circumstances. In many respects, the new EU members are still not in the stable state characteristic for the Western democracies. The core of all differences in citizens' perception lies quite likely in the Morgenthau's conclusion (1995), that the Western societies articulate higher level of internal social cohesion than external. Citizens in the old EU members predominantly articulate a traditional awareness of national states which is reflected in the high national consciousness and emphasis on sovereignty which is close to self-sufficiency.

As the result of political shocks in many new EU member states in the $20^{\text {th }}$ century, in the citizens' memory a historical experience with their own national states faded out, and some have never had it. We could also presume that transition to market economy and to democratic political system left consequences on individual citizens which significantly influence their personal values, perception of democracy and legal systems, and consequently their trust in national and EU institutions. There are no significant differences among Europeans regarding personal values related to inter-personal relations and moral principles. Differences are visible mainly in personal values that are in some way consequences of previously mentioned historical experiences. For example, in our research we identified such differences in citizens' perception of democracy and personal tolerance. 


\section{Marjetica Primožič, Cene Bavec \\ Personal values and trust of Europeans in national and EU institutions}

We were particularly provoked by statement that is quite often heard particularly in the political arena that people accept or reject EU on the basis of their personal values. There are very few researches that studied an interrelation between personal values and citizens' awareness of political institutions (Hudson, 2006). We could just mention related researches dealing with the social capital in Europe which also confirms significant differences between regions (van Schaik, 2002, Mihaylova, 2004, van Oorschot et al, 2005). However, social capital very remotely reflects personal values. We took the opportunity to use public opinion polls on personal values that was published by the European Commission in the Eurobarometers (2008). Our main goal was to examine relation between personal values and trust of Europeans in national institutions (national legal systems, national governments and national parliament) and trust in the EU institutions (EU as a political formation, European Commission and European Parliament). Furthermore, we were interested if this trust is shaped also by general characteristics of the legal environment in the particular country. Our assumption was that the legal system reflects historical circumstances under which the particular state was formed and consequently shapes individuals' awareness of their own country and the EU. Therefore, we indirectly included into our research the assumption that trust in institutions depended also on some historical circumstances.

In the research we did not elaborate economic issues mainly because we could not find objective evidence that the level of economic development influences citizens' trust in national or EU institutions. However, the current economic and consequently social crisis opens many intriguing questions on the future trust in national states and particularly in the EU. The recent events in Island and Ireland could lead to the conclusion that many things would be different after the end of the crisis, including awareness of the EU.

\section{Research goals and methodology}

\subsection{Research hypothesis}

In the presented research we used quantitative statistical methods to analyze differences between personal values and citizens' trust in national and EU political institutions. We also examined impact of different legal systems that are characteristical for individual country. Research was based on secondary 
Marjetica Primožič, Cene Bavec

Personal values and trust of Europeans in national and EU institutions

data from the European Commission's sources because any primary data collection would exceed the scope of the research group. On the other hand, we have at our disposal data at the EU level that have been collected with a common methodology. All statistical data we have used had been published in the Eurobarometer 69.

The research focused on hypotheses which are based on indices from different researches and some generally accepted assumptions in political and professional circles. We concentrated on three hypotheses that could be statistically accepted or rejected:

Hypothesis 1: Personal values of Europeans influence their trust in national and EU institutions.

Hypothesis 2: There are significant differences between the old and new EU member states in their citizens' trust in national and EU institutions.

Hypothesis 3: The type of legal system that characterizes particular country influences citizens' trust in national and EU institutions.

The first hypothesis reflects the already mentioned assumption that historical circumstances are echoed in the personal values which lead to different perception of national and particularly EU institutions. In the hypothesis we did not discuss history because we could not objectively define any statistically verifiable indicator. We concentrated directly on the personal values. The second hypothesis is based on the assumption that there are significant differences in this regard between the old and the new EU member states. These differences are quite often mentioned in political discussions although there are very few facts or researches that could confirm them. At least, it is difficult to put all new members into one homogenous group. We could argue that new member states are composed at least from two different groups that are differentiated by majority of social indicators. On one side are Cyprus and Malta; on the other are ten post-socialistic countries. The third hypothesis mirrors a widely noticed conviction that trust in national and international institutions is also a consequence of different legal systems. For example, we could see United Kingdom and its evroscepticism significantly deviating from other EU countries, or Scandinavian countries that are notably more benevolent to the idea of EU. Particularly this hypothesis grabbed our interest because we have not noticed many researches focusing on this issue. 


\subsection{Data used and course of the research}

The personal values are defined with twelve indicators (Table 1). They are selected from the regular statistical researches at the EU level (Eurobarometer, 2008). We opted for these indicators because they were publicly available. However, we were fully aware that with such selection we limited the validity our research. The personal values for every country are defined in the interval from 0 to 1.

Table 1: The personal values of Europeans

\begin{tabular}{|c|c|c|}
\hline $\begin{array}{l}\text { No. of the } \\
\text { question }\end{array}$ & $\begin{array}{l}\text { Question ID in the Eurobaro- } \\
\text { meter }\end{array}$ & The personal values of Europeans \\
\hline 1. & QD2 & Peace \\
\hline 2. & QD2 & Human rights \\
\hline 3. & QD2 & Respect for human life \\
\hline 4. & QD2 & Democracy \\
\hline 5. & QD2 & Individual freedom \\
\hline 6. & QD2 & The rule of law \\
\hline 7. & QD2 & Equality \\
\hline 8. & QD2 & Tolerance \\
\hline 9. & QD2 & Solidarity \\
\hline 10. & QD2 & Self-fulfillment \\
\hline 11. & QD2 & Respect for other cultures \\
\hline 12. & QD2 & Religion \\
\hline
\end{tabular}

Source: European Commission, Eurobarometer 69, 2008

Similar explanations are applicable for trust in national and EU institutions among Europeans (Table 2). In this case too, the trust is defined in the interval from 0 to 1. 
Marjetica Primožič, Cene Bavec

Personal values and trust of Europeans in

national and EU institutions

Table 2: Trust of Europeans in different institutions

\begin{tabular}{|c|l|l|}
\hline $\begin{array}{l}\text { No. of the } \\
\text { question }\end{array}$ & $\begin{array}{l}\text { Question ID in the Euroba- } \\
\text { rometer }\end{array}$ & The personal values of Europeans \\
\hline 1. & QA12.5 & Trust in national legal system \\
2. & QA12.9 & Trust in national government \\
3. & QA12.10 & Trust in national Parliament \\
4. & OA12.11 & Trust in the European Union \\
5. & QA18.1 & Trust in the European Parliament \\
6. & QA18.2 & Trust in the European Commission \\
\hline
\end{tabular}

Source: European Commission, Eurobarometer 69, 2008

The main objective of the research was the use of statistical methods to explore differences in citizens' trust between the EU countries. We intentionally reduced interpretation of results to a minimum to avoid any stereotype prejudices and misconclusions.

\section{Presentation of results}

\subsection{Clustering countries with regard to citizens' personal values}

The first step in the research was to see if the EU countries form any distinctive clusters with regard to their citizens' personal values. The idea behind the clustering was to compare the membership of these clusters with another set of clusters obtained with regard to citizens' trust in different political institution. If the membership of both sets of clusters would be similar or even equal than we would conclude that there is interdependence between two multi dimensional variables: personal values and trust. As the mathematical tool we used hierarchical cluster analysis which allows grouping of variables with a larger number of parameters. In our case, there were twelve different 
personal values for each EU country. The hierarchical cluster analysis also concentrates on samples (in our case countries) and not so much on parameters (in our case different personal values), as other statistical methods do. It also offers a simple and comprehensive visual interpretation of similarities between samples (countries), as it can be seen in the Figure 1.

Analyzing correlations between the individual personal values show that they are functionally independent. It proves that they were carefully selected in Eurobarometer research. Nevertheless, we can notice some interesting and statistically significant correlation that can be relevant for the interpretation of results. The correlation between the values "rule of law" and "solidarity" is negative ( $R=-0,673, p<0,01)$, as well as the correlation between the values "religion" and "tolerance" $(R=-0,608, p<0,01)$. Particularly interesting is the negative correlation between the values "self-fulfillment" and "human rights" $(R=-0,523, p<0,01)$.

\section{Figure 1: Clustering the EU countries with regard to citizens' personal values}

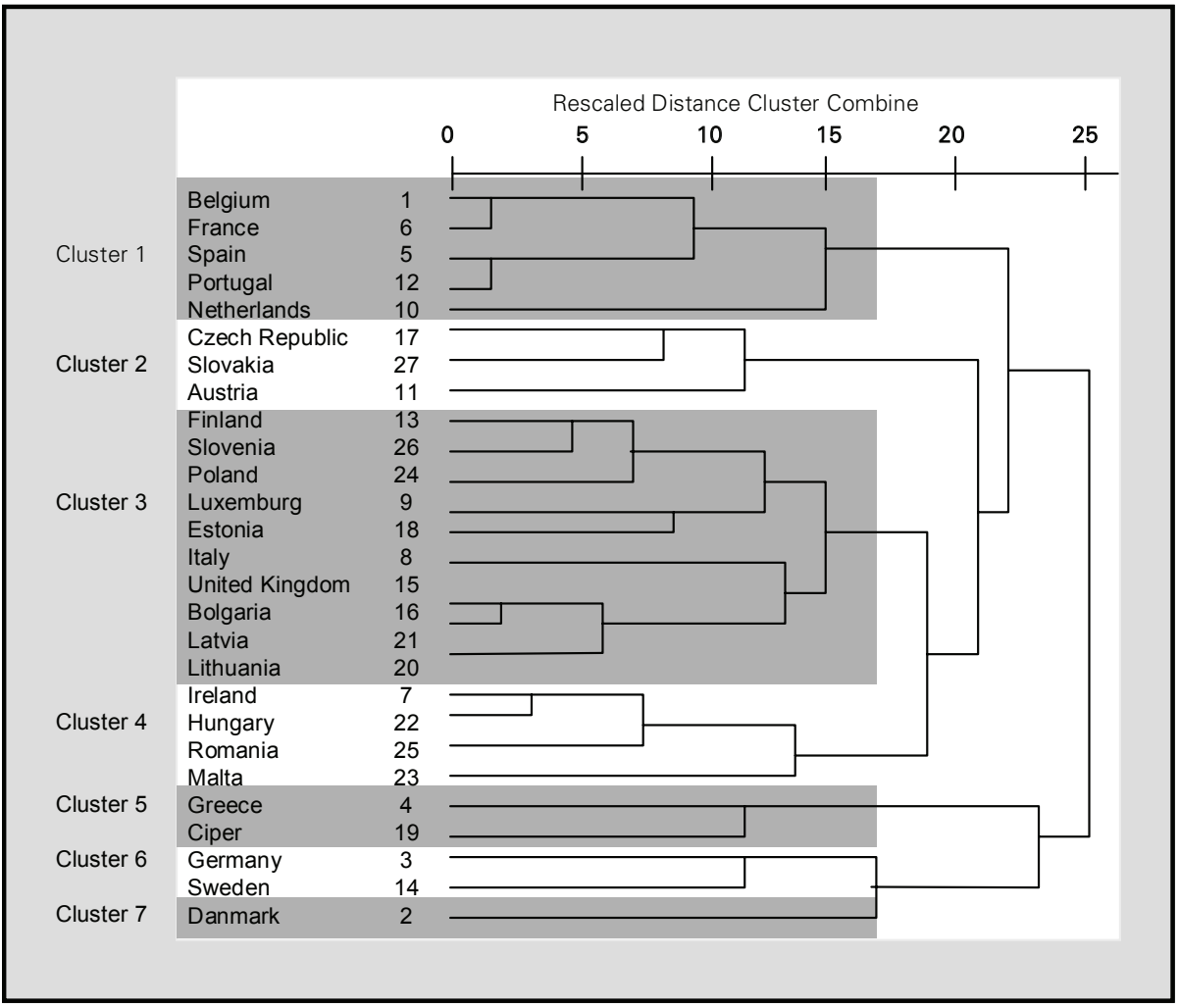




\section{Marjetica Primožič, Cene Bavec \\ Personal values and trust of Europeans in national and EU institutions}

The figure 1 shows similarities and clustering of the EU countries with regard to their citizens' personal values. The dendrogram does not indicate any ranking and any individual personal value. It just reveals similarities taking into account all twelve parameters simultaneously. If we move from the left side of the dendrogram to the right we can see which countries are the most similar and how they gradually form larger clusters (similar are the countries in the same hierarchy). In illustration, let's take the first four countries in the Cluster 1. We can easily notice the highest similarity between Belgium and France and also between Spain and Portugal. The personal values of the citizens of Belgium and France are very similar, as well as Spain and Portugal. It sounds quite reasonably because they are similar also by other criteria, not to mention the geographical vicinity. Moving towards the right side of the dendrogram similarities are smaller, but the clusters are larger. At the rescaled distance around nine these four countries form a larger cluster showing that they are mutually similar but different from members of other clusters. The same logic can be applied for all countries in the Figure 1.

The final clustering of the EU countries was made arbitrary at the rescaled distance seventeen. We got seven clusters that separate countries with different citizens' personal values. Clusters reveal that the personal values are not equal in all countries and that their distribution is not random over the territory of the EU. In the first cluster we can see just the old EU member states (Belgium, France, Spain, Portugal and Netherlands), in the second cluster there are three neighboring Central European countries (Czech Republic, Slovakia and Austria), and in the biggest third cluster there is already a mixture of the old and the new member states (Slovenia, Finland, Poland, Estonia, Luxembourg, Italia, United Kingdom, Bulgaria, Latvia, Lithuania). In the fourth cluster there are beside Ireland new EU member states (Ireland, Hungary, Romania, and Malta), in the fifth are Greece and Cyprus, in the sixth Germany and Sweden, and in the seventh just Denmark, so different in comparison with other countries that it forms its own cluster.

Because the third cluster is quite large we can refine our measurement of similarities and decide to break it into smaller clusters at the rescaled distance ten. In this case we get three sub-clusters. In the first there are Slovenia, Finland in Poland, in the second there are Estonia and Luxembourg, in the third there are Italy and United Kingdom, and in the fourth Bulgaria, Latvia and Lithuania. Obviously, it is up to us to decide how detailed clustering we would need for enhanced interpretation of results. 


\subsection{Clustering countries with regard to citizens" trust in institutions}

Based on the same methodology as described in the previous chapter we clustered EU countries with regard to citizens' trust in institutions. We used six parameters (Table 2). We can see at a glance that we have got four clusters with very different membership as in the case in the Figure 1, indicating that the personal values are not connected to the citizens' trust in national and EU institutions.

Figure 2: Clustering the EU countries with regard to citizens' trust in national and EU institutions

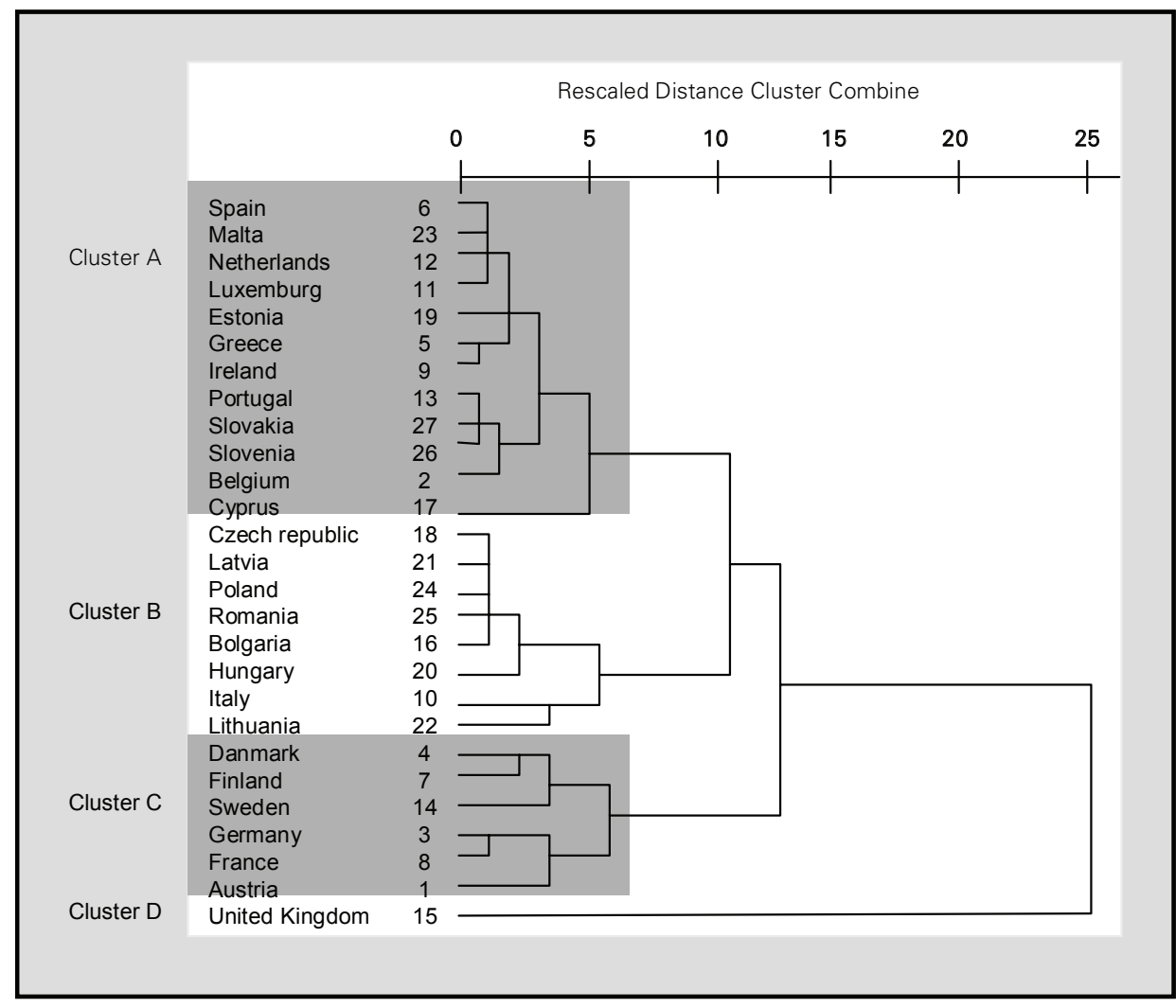

At the rescaled distance four we would get seven clusters, as in the case of the personal values, however in two clusters there would be just one country. For that reason we opted for less detailed clustering. At the rescaled distance seven we get four clusters. The Cluster A links very diverse group of 
Marjetica Primožič, Cene Bavec

Personal values and trust of Europeans in national and EU institutions

countries (Spain, Malta, Netherlands, Luxembourg, Estonia, Greece, Ireland, Portugal, Slovakia, Slovenia, Bulgaria and Cyprus). However, more detailed insight reveals that Cyprus is relatively unique, and all other are very similar. The Cluster B links together the new EU countries (Czech Republic, Lithuania, Poland, Romania, Bulgaria, Hungary and Latvia) and Italy. The Cluster C includes the most economically developed EU member states (Denmark, Finland, Sweden, Germany, France and Austria) and shows that their citizens have very similar trust in national and EU institutions, but quite different from other members. As we can see in the Figure 2, United Kingdom forms its own cluster that is significantly different from all others, even at the largest rescaled distance of twenty-five.

The membership of the clusters in the Figure 2 are significantly different from the membership of clusters in the Figure 1, revealing that the personal values have no evident effect on citizens' trust. For example, Germany, France and Austria have very similar attitude towards national and EU institutions (Figure 2), but very different personal values of their citizens (Figure 1). We confirmed the conclusion that the personal values are not related with trust in institutions also with bivariant correlations between individual personal values and trust in a particular institution. They are nearly all statistically insignificant. Nevertheless, we can confirm two related indicators that are interesting to notice. The correlation between the values of "democracy" and "trust in national institutions" is positive and statistically significant $(R=0,621, p<0,01)$, which is not the case with "trust in EU institutions". There is also relatively small but positive correlation between the value "solidarity" and "trust in EU institutions" ( $R=0,401, p<0,05)$, with no significant correlation with "trust in national institutions".

Factor analysis of parameters defining trust in institutions revealed that they are unambiguously divided by two factors: defining trust in national institutions and trust in EU institutions). Therefore we can introduce two new aggregate variables that can replace all others in our statistical analysis:

1. The average (aggregate) trust in national institutions;

2. The average (aggregate) trust in EU institutions; 
Marjetica Primožič, Cene Bavec

Personal values and trust of Europeans in national and EU institutions

Table 3: Average trust in institutions by EU countries and types of the legal system

\begin{tabular}{|c|c|c|c|}
\hline Country & $\begin{array}{c}\text { Average trust in } \\
\text { national } \\
\text { institutions }\end{array}$ & $\begin{array}{l}\text { Average trust in EU } \\
\text { institutions }\end{array}$ & Type of the legal system \\
\hline (1) & (2) & (3) & (4) \\
\hline Austria & 0,54 & 0,38 & German \\
\hline Belgium & 0,46 & 0,67 & Roman $f$ \\
\hline Bulgaria & 0,14 & 0,55 & Post-socialist countries $\left({ }^{*}\right)$ \\
\hline Cyprus & 0,66 & 0,66 & German \\
\hline Czech Republic & 0,23 & 0,55 & Post-socialist countries $\left({ }^{*}\right)$ \\
\hline Denmark & 0,71 & 0,55 & Scandinavian \\
\hline Estonia & 0,50 & 0,59 & Post-socialist countries $\left({ }^{*}\right)$ \\
\hline Finland & 0,69 & 0,50 & Scandinavian \\
\hline France & 0,36 & 0,46 & Roman \\
\hline Greece & 0,44 & 0,59 & German \\
\hline Ireland & 0,45 & 0,57 & Roman \\
\hline Italy & 0,21 & 0,46 & Roman \\
\hline Latvia & 0,19 & 0,54 & Post-socialist countries $\left({ }^{*}\right)$ \\
\hline Lithuania & 0,18 & 0,39 & Post-socialist countries $\left({ }^{*}\right)$ \\
\hline Luxembourg & 0,54 & 0,54 & Roman \\
\hline Hungary & 0,22 & 0,54 & Post-socialist countries $\left({ }^{*}\right)$ \\
\hline Malta & 0,54 & 0,60 & Roman \\
\hline Germany & 0,45 & 0,43 & German \\
\hline Netherlands & 0,57 & 0,59 & Scandinavian \\
\hline Poland & 0,25 & 0,54 & Post-socialist countries $\left({ }^{*}\right)$ \\
\hline Portugal & 0,36 & 0,61 & German \\
\hline Romania & 0,25 & 0,56 & Post-socialist countries $\left({ }^{*}\right)$ \\
\hline Slovakia & 0,34 & 0,64 & Post-socialist countries $\left({ }^{*}\right)$ \\
\hline Slovenia & 0,30 & 0,60 & Post-socialist countries $\left({ }^{*}\right)$ \\
\hline Spain & 0,55 & 0,61 & Roman \\
\hline Sweden & 0,57 & 0,47 & Scandinavian \\
\hline United Kingdom & 0,33 & 0,25 & Roman \\
\hline
\end{tabular}

Source: Author

Introduction of two new variables (columns 2 and 3 in the Table 3) makes much easier interpretations and understanding of results and also easier graphical presentation. The Figure 3 shows positions of countries with regard 
Marjetica Primožič, Cene Bavec

Personal values and trust of Europeans in national and EU institutions

to their average trusts in national and EU institutions. The inner coordinates dividing the graph into four quadrants are aligned by the average trust of citizens of all EU member states in national institutions $(0,41)$ and $E U$ institutions $(0,53)$ (Table 4). As we see, majority of the new EU members have higher trust in EU institutions than the EU average, but lower trust in national institutions than the EU average. On the other side, the old EU members demonstrate mostly higher trust in national institutions and are much divided in their citizens' trust in EU institutions. United Kingdom is quite unique with very low trust in national and even lower trust in EU institutions. If we concentrate on the few other extremes we can notice very low trust in national institutions in Italy and very high trust of citizens of Malta and Cyprus in EU institutions. It is in accordance with our previous conclusion that Malta and Cyprus are new EU members, but with significantly different citizens' values and trust in institutions than in other new members from the Central Europe and Baltic.

\section{Figure 3: Distribution of the EU countries with regard to citizens' average trust in national and EU institutions}

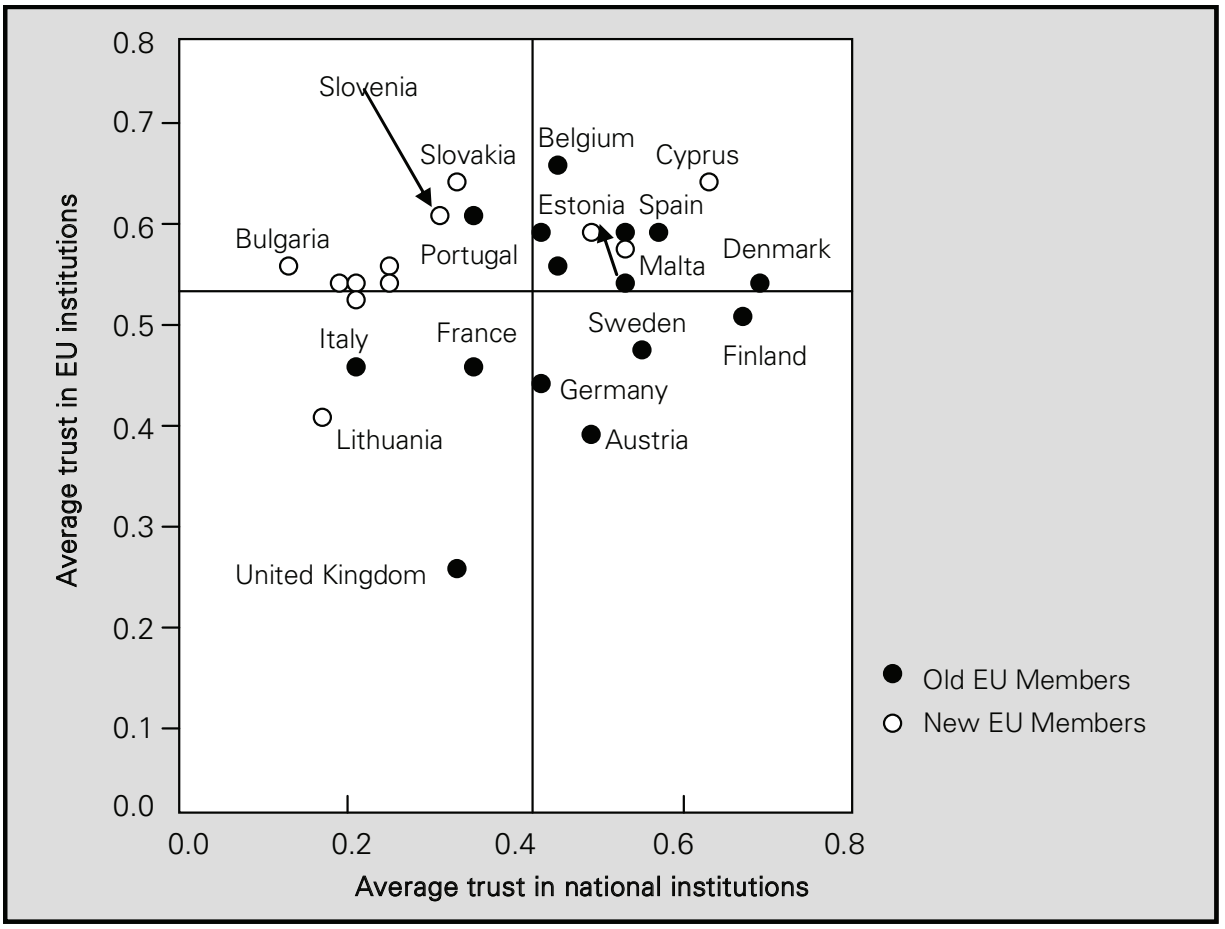

Grouping of new member states indicates certain regularities that are consequence of different common experiences. One of them is their recent 


\section{Marjetica Primožič, Cene Bavec \\ Personal values and trust of Europeans in national and EU institutions}

history and entrance to the EU. Widespread interpretation is that in the phase of negotiations and conformation of their legal systems to the EU acquis communautaire consequently lead to nearly automatic adoption of EU directives. In the eyes of citizens it put the national institutions into a second-class position in comparison with the EU institutions and it also left an impression that EU institutions are generally more democratic and efficient. Another explanation says that there are also historical reasons that shaped citizens' perception and trust. We have already mentioned Morgenthau's (1995) view on the Western European national states. For that reason we hypothesize that basic characteristics of the legal system in particular country or region significantly shape citizens' trust in different political institutions.

To verify this assumption we grouped EU member states also with regard to the type of the legal systems (Table 3 ) that predominantly reflects their current legal regulation (Arminjon, at al, 1952, Zweigert in Kötz, 1998, Grasmann, 1998):

1. Scandinavian

2. German

3. Anglo-American (Common Law)

4. Roman

5. Post-socialistic countries.

We have to emphasize that this classification is not black-and-white because in some cases we have dilemmas how to classify a particular country. For that reason we can just talk about prevailing characteristics of the legal system in the country. Postsocialist countries are deliberately not classified by the type of the legal systems because we presumed that historical reflexes had much more significant effect on the citizens' trust than the current legal system in majority of cases still in phase of consolidation. For the purpose of our study they are all labeled as post-socialist countries $\left({ }^{*}\right)$.

Statistically significant differences at $p=0,01$ between countries with different type of the legal system are present just in the case of trust in national institutions. Countries with the Scandinavian type of the legal system have very high trust in national institutions $(0,64)$, meanwhile the trust in postsocialistic countries is nearly three times lower $(0,26)$. 
Marjetica Primožič, Cene Bavec

Personal values and trust of Europeans in

national and EU institutions

Table 4: Average trust in institutions

\begin{tabular}{|l|c|c|}
\hline & $\begin{array}{c}\text { Average trust in national } \\
\text { institutions }\end{array}$ & $\begin{array}{c}\text { Average trust in EU } \\
\text { institutions }\end{array}$ \\
\hline EU average & 0,41 & 0,53 \\
Average in the old EU members & 0,48 & 0,51 \\
Average in the new EU members & 0,32 & 0,56 \\
\hline \multicolumn{1}{|c|}{ Type of the legal system: } & & 0,53 \\
\hline Scandinavian & 0,64 & 0,57 \\
German & 0,49 & 0,47 \\
Anglo-American (Common Law) & 0,44 & 0,55 \\
Roman & 0,42 & 0,55 \\
Post-socialistic countries & 0,26 & \\
\hline
\end{tabular}

Source: Author

We cannot notice these differences with regard to the trust in EU institutions that are in the interval from 0,47 to 0,57 , and are not statistically significant. It is also interesting that statistical One-way ANOVA test confirms that the personal values have no relationship with the legal systems, except for the value "democracy" which is different in different legal systems ( $F=5,29$, $\mathrm{p}=0,004)$. Democracy is highest valued in the Anglo-American $(0,38)$ and the German legal type $(0,31)$, and far the lowest in post-socialistic countries $(0,20)$.

\subsection{Confirmation of hypothesis}

Comparing the membership of two sets of country clusters with regard to their citizens' personal values (Figure 1) and citizens' trust in institutions (Figure 2) we can confirm that these two multidimensional variables are not related. This conclusion is confirmed also by analyzing bivariate correlations between individual personal values and average trusts in national and EU institutions which are statistically relevant just for two already mentioned parameters. It means that large majority of personal values do not influence citizens' trust in institution, so we consequently rejected the first hypothesis which claims that this influence exists. 


\section{Marjetica Primožič, Cene Bavec \\ Personal values and trust of Europeans in national and EU institutions}

The average trust in national institutions in the old EU member states is 0,48 and in the new only 0,32 (Table 4). Differences in trust in EU institutions is much lower; 0,51 in the new and 0,56 in the old member states. However, the differences in the group of the old members are very dispersed, from eurosceptics like United Kingdom and Austria to noticeably favorable attitudes in Belgium, Portugal or Spain. Meanwhile, trust in EU institutions is nearly equal in the new member states. All mentioned differences are statistically significant at $p=0,01$, so we can accept the second hypothesis which anticipates that there are significant differences between the new and old EU member states with regard to citizens' trust in national and EU institutions.

The third hypothesis is partially accepted and partially rejected. We accepted the first part of the hypothesis which claimed that the characteristics of the national legal system influence citizens' trust in national institutions, but we rejected the second part which assumed the same for the trust in the EU institutions. We have to emphasize that we treated all post-socialist countries as one group. If we would classify them with regard to the type of the present legal system we would see that majority of them formally belong to the German type and two or three to the Scandinavian type. In this case we should more carefully interpret results because the German type would be composed of two quite different groups of countries with significantly different trust in institutions.

\section{Conclusions}

As Morgethau (1995) argued, people comprehend only the ideas that reflect circumstances in which they live. This is also true for citizens of the EU member states which shape their perception of national states and the EU in the framework of their experience from their economic, social and political environment. For that reason, understanding their trust in different institutions indirectly means understanding their living environment. Our study confirmed some known premises, but we also enlightened some less obvious relations. As we stressed when we presented the research hypothesis, all the hypothesis look acceptable because they reflect a common perception and even stereotypes. Nevertheless, our hypotheses have been just partially confirmed because things are not always as they look. The conclusion that personal values have no effect on the individuals' trust in the national state or in the EU is not so obvious. Only the values of "democracy" and "solidarity" are connected with 
Marjetica Primožič, Cene Bavec

Personal values and trust of Europeans in national and EU institutions

trust in institutuons. In the countries where citizens value democracy very high they also show very high trust in the national institutions, on the other side in countries with high value of solidarity higher trust in the EU institutions prevails. Without detailed elaboration we might conclude that for Europeans the EU doesn't look very democratic, but it definitely means solidarity.

Because the personal values are not linked to trust in institutions it is obvious that the reasons for differences between countries and regions lies somewhere else. Our research suggests that one of the reasons could be their history and consequently the type and also stability of the legal system. Trust in national institutions is very high in countries with Scandinavian type of legal systems, in other countries is average, and it is very low in post-socialistic countries. Research also confirmed a widely spread opinion that there are differences between old and new EU member states. It is particularly intriguing fact that citizens in new member states demonstrate significantly higher trust in EU institutions than national. On the other side, it is obviously very hard for the citizens of the old EU member states to give up some of their state attributes on the account of the EU. In our research we did not elaborate the often negative attitude of old EU members toward new member states, which is an additional burden in their relation to enlarged EU. Researches that were conducted decade ago revealed significantly higher homogeneity and feeling of affiliation to the European association of that time.

However, trust of citizens in the old EU member states is evidently split and range from distrust to trust. It is obvious that in these countries there are also other reasons that shape perception of political institutions of the EU citizens. Partially, we addressed these issues with differences in their legal systems. However, it is still an open question and has not been elaborated in our research in detail. We did not go into deeper interpretations, leaving them to experts from these fields. Our goal was to present data and statistically provable interrelations that could contribute to objective interpretations from different points of view. 
Marjetica Primožič, Cene Bavec

Personal values and trust of Europeans in national and EU institutions

Marjetica Primožič works in the Sector for Analysis and Monitoring in the Slovenian Research Agency. She was the Head of the International Relations and was responsible for bilateral cooperation. In the ministry responsible for science and technology she participated in preparation and implementation of many international agreements. She was also involved in writing different analytical and promotional publications published by the ministry.

Dr. Cene Bavec is Associate Professor at the Faculty of Management Koper, University of Primorska. His previous duties include among others the positions of the State Secretary for Technology, Dean of the School of Management, and IBM University Relations Manager for Central Europe and Russia. His academic interests are particularly organization science and management of information technologies. 


\section{Marjetica Primožič, Cene Bavec \\ Personal values and trust of Europeans in national and EU institutions}

\section{References}

- Adam, F., Roncevic, B. (2005). Social Capital: Recent Debates and Research Trends, Social Science Information, 42(2), 155-183

- Anderson, J. J. (ed) (1999). Regional Integration and Democracy, Rowman \& Littlefield

- $\quad$ Arminjon, P., Nolde, B., Wolff, M. (1952). Traité de droit comparé, T. III, Revue internationale de droit comparé, Volume 4, Issue 1, str. 166-167

- $\quad$ Bavec, C. (2007). Interdependence between social values and national performance indicators: the case of the enlarged European Union. Managing global transitions, vol. 5 no. 2 , str. 213-228.

- Grasmann, G. (1998). Uvod v velike pravne sisteme, (Slovenian edition), Prva knjiga, Cankarjeva založba, Ljubljana

- Halman, L. (2001). The European Values Study: a Third Wave: Source Book of the 1999/2000 European Values Study Survey, Tilburg University, http://www2.warwick .ac.uk/ fac/soc/wbs/conf/olkc/archive/olkc1/papers/512_lam.pdf

- Hofstede, G. (1998). Attitudes, Values and Organizational Culture: Disentangling the Concepts, Organization Studies, Vol. 19, No. 3, str. 477-493.

- Hudson, J. (2006). Institutional Trust and Subjective Well-Being across the EU, Kyklos, Vol. 59, No. 1, str. 43-62

- Kaase, M. (1999). Interpersonal trust, political trust and non-institutionalised political participation in Western Europe, West European Politics, vol. 22, no. 3, str. 1 - 21

- McLaren, L. M. (2002). Public Support for the European Union: Cost/Benefit Analysis or Perceived Cultural Threat?, The Journal of Politics, Cambridge University Press

- Mihaylova, D. (2004). Social Capital in Central and Eastern Europe. A Critical Assesment and Literature Riview. Budapest: Center for Policy Studies at the Central European University.

- Morgenthau, H. (1995). Politika med narodi, (Slovenian edition), DZS, Ljubljana

- Newton, K. (2001). Trust, Social Capital, Civil Society, and Democracy, International Political Science Review, Vol. 22, No. 2, 201-214

- Oorschot van, W., Arts, W. (2005). The Social Capital of European Welfare States - The Crowding out Hypothesis Revisited. Journal of European Social Policy. 15 (1). 5-26 
Marjetica Primožič, Cene Bavec

Personal values and trust of Europeans in national and EU institutions

- Patrick, F., Zabojnik, J. (2005) Trust as Social Capital and the Process of Economic Development. Journal of the European Economic Association. 3 (1). 51-94.

- Schaik van, Ton. (2002). Social Capital in the European Values Study Surveys. Tilburg: Tilburg University. Netherlands. http://www.oecd.org/dataoecd/22/22/2381883.pdf

- Zweigert, K., Kötz, H. (1998). An Introduction to Comparative Law, Clarendon Press; 3 edition

- (2008). Eurobarometer 69, European Commission, Brussels 